\title{
ЦИФРОВІ ТЕХНОЛОГІї ЯК ЧИННИК ВПЛИВУ НА МОДЕРНІЗАЦІЮ ЦИВІЛЬНИХ ВІДНОСИН
}

\author{
СВІТЛАК І.І. - кандидат юридичних наук, доцент, завідувач кафедри \\ правознавства i гуманітарних дисциплін Вінницького навчально-наукового \\ інституту економіки Західноукраїнського національного університету \\ ORCID: 0000-0002-4408-6868 \\ DOI 10.32782/LAW.UA.2021.2.20
}

\begin{abstract}
У статті представлено теоретико-правове дослідження впливу ицфрових технологій на структуру иивільного правовідношення. Обгрунтовано, шо наслідком поширення прощесів ицфбровізаий всіх сфер суспільного життя стала поява нових об’єктів із використанням штучного інтелекту, робототехніки, технологій блокчейн у різних сферах сочіальної діяльності: управління державою, Індустрї 4.0, транспорту, роздрібної торгівлі, послуг, охорони здоров'я, інфраструктури міст тощо.

Окремі ознаки ицфровізованих явищ аналізуються з точки зору чивільно-правової науки. Відзначаючи мультидисииплінарну природу проблем діджиталізацї різних сфер суспільного життя констатується відсутність правил та регламентів використання даних, існування проблем захисту інтелектуальної власності та захисту даних.

Висловлена думка, що основними наслідками впливу сучасних ицфрових технологій на модибікацію иивільних відносин $є$ поява нових об'єктів та віртуалізація суб'єктів. У зв'язку 3 чим, у сучасній юридичній науці спостерігається наукова дискусія щодо визначення правової природи штучного інтелекту, ботів та критеріїв їх ідентибікачій. Визначено, що визнання штучного інтелекту та робота об'єктом чи суб'єктом иивільних прав (правовідносин) потребує подальших комплексних досліджень. На підставі аналізу чинного законодавства у досліджуваній сбері сформульовані висновки щодо суб'єктів та об'єктів циивільних відносин, які виникають внаслідок иифровізациї. Досліджуючи
\end{abstract}

зміст иливільного правовідношення, відзначено, що відсутність у громадян достатніх компетентностей роботи з даними (иифрових навичок), відповідної освіти, професій $\epsilon$ поширеним явищем. Відзначено, що криза, зумовлена пандемією COVID-19, активізувала чиффровізачію публічної і приватної сфер суспільного життя.

Констатується, що традиційні особисті немайнові та майнові права учасників цивільних відносин трансбормуються, набуваючи нового змісту. У висновках підкреслюеться не тільки дискусійність питання впливу ицфрових технологій на ицвільні відносини та необхідність модернізацй цивільно-правового регулювання відносин з використанням иифрових об'єктів, цифбрових платборм, иибрових послуг, але $і$ доктринального коригування конщепщй регулювання цивільних відносин в умовах ицифровізащй 3 урахуванням досвіду країн $E C$.

Ключові слова: ичибровізаиія, ииџброві технологї, цивільні правовідносини, суб'єкт цивільних правовідносин, об'єкт цивільних правовідносин, зміст иивільних правовідносин, ицфрові права, штучний інтелект, віртуальне підприємство.

\section{Постановка проблеми}

Процеси тотального впровадження цифрових технологій майже в усі сфери суспільного життя неминуче призводять до трансформації та модернізації сучасних правовідносин, а також появи нових суспільних відносин, що потребують формування відповідного нормативно-правового забезпечення. Цифровізація сфери послуг та зростаючий попит на онлайн сервіс останнім 


\section{Цивільне, підприсмницьке, господарське та трудове право}

часом обумовлені вжиттям карантинних обмежень, встановлених для запобігання поширенню пандемії короновірусної хвороби. За таких умов спостерігається збільшення кількості споживачів онлайн послуг у різних сферах обслуговування (онлайн банкінг, онлайн консультування, дистанційне навчання тощо стали звичайними явищами). У зв'язку з цим, актуалізується дослідження питань впливу цифрових технологій на цивільні відносини з надання послуг у режимі онлайн, появи нових об'єктів цивільних правовідносин, захисту прав споживачів таких послуг, змісту цифрових прав та обов'язків суб'єктів, модернізації цивільного законодавства.

\section{Аналіз останніх досліджень i публікацій}

Останнім часом у юридичній науці пожвавився науковий інтерес до висвітлення різних аспектів впровадження цифрових технологій в окремі сфери суспільного життя. Заслуговують на увагу наукові висновки та спостереження, сформульовані провідними вітчизняними науковцями у галузі цивільного та господарського права, теорії права, цифрових трансформацій, зокрема: О.А. Баранова, О.А. Беляневич, О.М. Вінник, О.М. Гончаренко, К.В. Ефремової, В.В. Кочина, Н.О. Левицької,Н. Б. Пацурії, Є.О. Харитонова, О.І. Харитонової та ін. Незважаючи на значний доробок учених, аналіз трансформацій, які відбуваються в структурі цивільних відносин під впливом діджиталізації, потребує подальшого мультигалузевого та комплексного дослідження. Цифровізація у приватній сфері породжує ряд проблем як теоретико-методологічного, так і практичного характеру.

Не вирішені раніше частини загальної проблеми

Вплив цифрових трансформацій на цивільні відносини досліджується в площині модернізації складових елементів правовідносин (об'єкт, суб'єкт, зміст). 3 огляду на вищевикладене, теоретичні дослідження окремих аспектів цифровізації приватноправової сфери здійснюється у контексті мо- дернізації цивільного законодавства в умовах пандемії COVID-19.

\section{Формулювання цілей статті}

Метою статті $\epsilon$ аналіз особливостей впливу нових цифрових технологій на приватно-правову сферу суспільних відносин в умовах пандемії короновірусної хвороби, у результаті чого визначити характер та наслідки (позитивні та негативні) таких змін, а також напрямки подальшої модернізації цивільного законодавства.

\section{Виклад основного матеріалу дослідження}

Запровадження низки карантинних обмежень задля запобігання поширенню коронавірусної хвороби (COVID-19) безсумнівно, вплинуло на всі сфери суспільного життя. Попри негативні наслідки поширення пандемії у всьому світі, саме пандемія прискорила переорієнтацію вітчизняної сфери послуг на віртуальне середовище, адже традиційні форми обслуговування в умовах дії карантинних обмежень уже не здатні задовільнити потреби споживачів. Саме зростаючий попит на зручне, комфортне та доступне дистанційне обслуговування активізував стрімку цифровізацію сфери, спричинивши подальшу трансформацію цивільних відносин.

У Концепції розвитку цифрової економіки та суспільства України на 2018-2020 роки під цифровізацією розуміється насичення фізичного світу електронно-цифровими пристроями, засобами, системами та налагодження електронно-комунікаційного обміну між ними, що фактично уможливлює інтегральну взаємодію віртуального та фізичного, тобто створює кіберфізичний простір [1]. Концептуально основну мету цифровізації визначено як трансформацію сфер життєдіяльності у нові більш ефективні та сучасні, отож основне завдання впровадження цифрових технологій - поліпшення різних сфер життєдіяльності людини.

Науковий інтерес викликають результати досліджень проблем правової регламентації відносин цифрової економіки. На думку О.А. Баранова, досягнення вищевказаної мети можливе в умовах формування 
нової моделі світової економіки - економіки результату. «Економіка результату - це людиноцентристська економіка 3 величезним ресурсозберігаючим та інноваційним потенціалом, зі зміненою природою екосистем коопераційного взаємодії і конкуренції, що базується на глобальній соціотехнологічній інфраструктурі (інфраструктурі IоT)» [2,c. 16].

Слушною є позиція О.М. Вінник, яка на підставі грунтовного аналізу практики використання цифровізованих явищ (штучного інтелекту, віртуальних підприємств, бізнессайтів тощо) та проблем правового регулювання цифровізації економіки відзначає неоднозначність цих процесів [3, с. 60].

Діджиталізація відбувається не лише в різних сферах господарської діяльності, цифрові технології істотно впливають і на приватну сферу. Особливо це стало помітним в умовах соціального дистанціювання та самоізоляції через пандемію короновірусної хвороби, адже за останній рік надзвичайно швидко цифровізувалась приватна сфера, а саме сфера обслуговування і саме дистанціювання громадян як споживачів різноманітних послуг змусило опановувати цифрові навички навіть ті верстви населення, які дотепер не відчували ніякої потреби у цифрових знаннях.

Сфера фінансових (банківських та небанківських послуг) зазнала значного прогресу 3 дистанційного (онлайн) обслуговування клієнтів. Жорстка конкуренції на ринку таких послуг стала поштовхом до впровадження нових сервісів онлайн платежів, частка яких сьогодні невпинно зростає.

Як зазначається у Стратегії розвитку фінтеху в Україні до 2025 року, події сьогодення в умовах світової пандемії коронавірусу COVID-19 демонструють стрімкий злет обсягів електронної комерції та попиту на онлайн-продукти фінансового ринку. Збільшення чисельності користувачів мобільних пристроїв та потужне поширення електронної комерції сприяе швидкій адаптації цифрових платежів у всьому світі. В Україні електронна комерція демонструє високу динаміку розвитку, стимулюючи кількість та обсяги безготівкових операцій [4]. Задля створення сучасної фінтех-екосистеми 3 ін- новаційними фінансовими сервісами та доступними цифровими послугами НБУ приєднався до Глобальної мережі фінансових інновацій.

Запровадження жорстких карантинних заходів через пандемію впродовж останнього року призвели також до широкого застосування цифрових технологій не тільки у транзакційно-процесинговому секторі, у сфері провадження е-комерції, але і в інших сферах життєзабезпечення, зокрема у сфері освіти (підвищення кваліфікації, отримання нових знань та навичок), охорони здоров'я, транспорту та логістики, надання аутсорсингових послуг, шляхом застосування цифрових платформ, хмарних сервісів, штучного інтелекту, віртуального середовища тощо.

Подібна цифровізація приватно-правової сфери потребує оцінки як з прикладної точки зору, зокрема в питаннях розробки відповідного ефективного нормативно-правового забезпечення цих процесів, так і доктринального науково-теоретичного аналізу впливу цих процесів на модифікацію цивільних правовідносин. Мова йде про модифікацію визначених цивільно-правової доктриною структурних елементів цивільного правовідношення (об’єкт, суб'єкт, зміст) під впливом цифрових технологій.

Перелік об'єктів цивільного правовідношення нормативно визначений у ст. 177 ЦК України. Зокрема, об'єктами цивільних прав $є$ речі, у тому числі гроші та цінні папери, інше майно, майнові права, результати робіт, послуги, результати інтелектуальної, творчої діяльності, інформація, а також інші матеріальні і нематеріальні блага [5]. У законодавчому переліку не вказані нові об'єкти, які з'явились завдяки цифровим технологіям інтернет речей, роботизації, кіберсистем, штучного інтелекту, хмарним обчисленням, блокчейн тощо. Хоча на невичерпність нормативного переліку об'єктів правовідносин вказує норма «... а також інші матеріальні і нематеріальні блага». Цілком зрозуміло, що такий перелік нових об'єктів на кшталт криптовалюти, віртуальних послуг, віртуальних речей та ін., створених шляхом цифровізації всіх сфер суспільного життя постійно доповнюється, що обумовлено стрімким розвитком цифрових технологій, інновацій, 


\section{Цивільне, підприємницьке, господарське та трудове право}

науки і техніки, що, у свою чергу, передбачає необхідність встановлення правового режиму віртуальних об'єктів.

Відповіднодост. 2 ЦК України суб'єктами цивільних відносин є фізичні особи та юридичні особи; держава Україна, АРК, територіальні громади, іноземні держави та інші суб'єкти публічного права [5]. Цифровізація впливає і на цей елемент правовідношення, адже вже сьогодні в наукових колах точаться дискусії не тільки з приводу визначення правового статусу/режиму віртуальних юридичних осіб, штучного інтелекту, ботів, але і вирішення принципового питання - є вони об'єктом чи суб'єктом правовідносин?

Щодо визначення місця штучного інтелекту у праві заслуговують на увагу міркування, висловлені Н. Марценко, на думку якої створення законодавчої бази людиною деякою мірою привілеює ії, ставить на особливе місце в сучасному світі. Людина була першим суб'єктом права, однак із розвитком суспільних відносин об'єктивно стала не єдиним носієм прав. На рівні із людиною самостійними суб'єктами цивільних прав є юридична особа, держава, територіальні громади. Питання розширення кола суб'єктів цивільного права особливо цікаве та дискусійне з позиції аналізу Резолюції Европейського Парламенту 2015/2103(INL), положення якої передбачають специфічний правовий статус для розумних роботів. Відповідно до положень Резолюції, особливим правовим статусом може бути наділена «електронна особа». Фактично, йде мова про присвоєння правового статусу розумним роботам, які можуть самостійно встановлювати взаємозв'язки із навколишнім середовищем та змінювати свої дії відповідно до ситуації [6, с. 93].

У зв'язку з вищевикладеним, вбачається, що сучасна концепція регулювання цивільних відносин потребує модернізації, а законодавство - усунення прогалин, шляхом визначення правового режиму нових об'єктів та визначення чітких критеріїв правової ідентифікації віртуальних цифрових квазісуб'єктів.

Цілком зрозуміло, що цифрові трансформації призводять і до модифікації змісту цивільного правовідношення, який $\epsilon$ структурним елементом правовідносин i становить сукупність цивільних прав та обов'язків суб'єктів. Поява нових об’єктів та віртуалізація суб'єктного складу внаслідок впровадження цифрових технологій невпинно спричиняє трансформацію змісту цивільного правовідношення. Зміст та правова природа цифрових прав, особливості їх здійснення та захисту потребує доктринального розв'язання 3 врахуванням передових світових практик нормативної регламентації та визначення правової природи нових об'єктів цивільних прав.

Традиційні (особисті немайнові та майнові права) суб'єктів цивільних правовідносин змінюються та наповнюється модерним змістом. Безпосередньо на таку модифікацію впливає запровадження цифрових технологій у цивільний оборот. Майнові цифрові права характеризуються передаваним (відчужуваним) характером та мають матеріальний зміст, на відміну від цифрових особистих немайнових прав. Зміст цивільних правовідносин становлять не тільки суб'єктивні цивільні права, але і обов'язки, що обумовлені виконанням цих прав.

Оцінка цифрових прав характеризується мультигалузевим підходом. Відповідно до Концепції розвитку цифрової економіки та суспільства України на 2018-2020 роки цифровізація повинна забезпечувати кожному громадянинові рівний доступ до послуг, інформації та знань, що надаються на основі інформаційно-комунікаційних та цифрових технологій [1].

Нещодавно уряд схвалив Концепцію розвитку цифрових компетентностей, основними завданнями якої 6 :

- формування та розвиток цифрових навичок та цифрових компетентностей у суспільстві;

- забезпечення правового регулювання з питань формування державної політики у сфері розвитку цифрових навичок та цифрових компетентностей громадян;

- розроблення комплексних змін до законодавства, що забезпечить визначення цифрової освіти, цифрових навичок та цифрових компетентностей у сферах суспільного життя;

- визначення системи та опису складових цифрової компетентності (рамки 
цифрової компетентності), а також вимог до рівня володіння цифровими навичками та цифровими компетенціями різних категорій працівників, зокрема в професійних стандартах;

- забезпечення координації дій на рівні органів виконавчої влади з питань розвитку цифрових навичок та цифрових компетентностей;

- створення індикаторів для моніторингу стану розвитку цифрових навичок та цифрових компетентностей;

- підвищення рівня обізнаності громадян щодо небезпек в Інтернеті [7].

Доцільність та прогресивність положень цієї Концепції очевидна. Цифрова грамотність громадян дозволяє не тільки оптимізувати різні бізнес-процеси, задовольняти власні побутові потреби, а також самостійно створювати нові віртуальні продукти та послуги, застосовуючи власні знання технологій Інтернету речей, віртуальної реальності, хмарних сервісів, штучного інтелекту.

\section{Висновки}

Цифровізація всіх сфер суспільного життя сьогодні $є$ світовим трендом, оскільки цифрові технології не тільки надають нові можливості, але стали запорукою процвітання багатьох країн світу.

Питання впливу цифрових технологій на цивільні відносини залишається дискусійним та остаточно не вирішеним, що, у свою чергу, вимагає не тільки модернізації цивільно-правового регулювання відносин з використанням цифрових об'єктів, цифрових платформ, цифрових послуг, але і доктринального коригування концепції регулювання цивільних відносин в умовах цифровізації та з урахуванням досвіду країн $\mathrm{EC}$.

Актуалізація проблем адаптації цивільно-правового регулювання до можливостей застосування цифрових технологій потребує подальших грунтовних теоретико-правових досліджень та формування нормативно-правової бази.

\section{\ітература}

1. Про схвалення Концепції розвитку цифрової економіки та суспільства України на 2018-2020 роки та затвердження плану заходів щодо їі реалізації: Розпорядження КМУ № 67-р від 17.01.2018 р. Дата оновлення: 17.09.2020. URL: https://zakon.rada.gov. ua/laws/show/67-2018-\%D1\%80\#Text (дата звернення: 10.03.2021).

2. Баранов О.А. Економіка результату, інтернет речей та право / Соціальна і цифрова трансформація: теоретичні та практичні проблеми правового регулювання: матеріали науково-практичної конференції, м. Київ, 10 грудня 2020 р. / упоряд.: О.А. Баранов, В.М. Фурашев, С.О. Дорогих. Київ: Фенікс, 2020. C. 10-19.

3. Вінник О.М. Переваги та ризики цифровізації економіки: проблеми правового регулювання. Підприємниитво, господарство і право. 2020. № 3. С. 56-62.

4. Стратегія розвитку фінтеху в Україні до 2025 року. URL: file://C:/Users/User/ Downloads/Strategy_finteh2025\%20(5).pdf (дата звернення: 20.03.2021).

5. Цивільний кодекс України: Закон України від 16.01.2003 р. № 435-IV. Дата оновлення: 01.01.2021. URL: https:/zakon. rada.gov.ua/laws/show/435-15\#Text (дата звернення 10.03.2021).

6. Марценко Н. Правовий режим штучного інтелекту у цивільному праві. Актуальні проблеми правознавства. 2019. № 4. С. 91-98.

7. Концепція розвитку цифрових компетентностей: Розпорядження Кабінету Міністрів України від 03.03.2021 р.№ 167-p. URL: https:/zakon.rada.gov.ua/laws/ show/167-2021-\%D1\%80\#Tеxt (дата звернення: 10.03.2021).

\section{References:}

1. Cabinet of Ministers of Ukraine (2018), "Resolution of the Cabinet of ministers of Ukraine "On approval of the Concept of development of the digital economy and society of Ukraine for 2018-2020 and approval of the action plan for its implementation",", available at: https://zakon.rada.gov.ua/laws/show/67-2018\%D1\%80\#Text (Accessed 10 March 2021).

2. Baranov, O.A. (2020), "Economics of results, the internet of things and law", Sotsial $\square n a$ $i$ tsyfrova transformatsiya: teoretychni ta praktychni problemy pravovoho rehulyuvannya: materialy naukovo-praktychnoyi konferentsiyi [Social and digital transformation: theoretical and practical prob- 


\section{Цивільне, підприсмницьке, господарське та трудове право}

lems of legal regulation: materials of the scientific-practical conference], Kyiv, Ukraine, pp. 10-19.

3. Vinnyk, O.M. (2020), "Advantages and risks of digitalization of the economy: problems of legal regulation", Pidpryyemnytstvo, hospodarstvo $i$ pravo, vol. 3, pp. 56-62.

4. National Bank of Ukraine (2020), "Strategy of fintech development in Ukraine until 2025", available at: file://C:/Users/User/ Downloads/Strategy_finteh2025\%20(5).pdf (Accessed 10 March 2021).

5. The Verkhovna Rada of Ukraine (2003), The Law of Ukraine "The Civil Code of Ukraine", available at: https://zakon.rada.gov. ua/laws/show/435-15\#Text (Accessed 10 March 2021).

6. Martsenko N. (2019), "Legal regime of artificial intelligence in civil law", Aktual'ni problemy pravoznavstva, vol. 4, pp. 91-98.

7. Cabinet of Ministers of Ukraine (2020), "Resolution of the Cabinet of ministers of Ukraine "On the concept of digital competence development"”, available at: https://zakon.rada. gov.ua/laws/show/167-2021-\%D1\%80\#Text (Accessed 10 March 2021).

I. Svitlak

Candidate of Juridical Sciences, docent, Head of the Law and Humanities Department Vinnytsia

Education and Research Institute of Economics (branch of West Ukrainian National University), Gonty Street, 37, city of Vinnytsya, 21017, Ukraine, tel.: (0432) 5532 31, e-mail: svitlakiryna@gmail.com

ORCID: 0000-0002-4408-6868

DIGITAL TECHNOLOGIES AS AN INFLUENCE FACTOR ON THE MODERNIZATION OF GIVIL RELATIONS

The article presents a theoretical and legal study of the impact of digital technologies on the structure of civil legal relations. It is substantiated that the consequence of the spread of digitalization processes in all spheres of social life was the emergence of new objects using artificial intelligence, robotics, law-making, blockchain technology in various areas of social activity: government management, Industry
4.0, transport, retail, health, urban infrastructure and the like.

From the point of view of civil law science, certain features of the digital phenomena are analyzed. Noting the multidisciplinary nature of the problems of digitalization of various spheres of social life, the absence of a system of rules, regulations of data use, the existence of problems of intellectual property protection and data protection are stated.

An opinion is expressed that the main consequences of the influence of modern digital technologies on the modification of civil relations are the emergence of new objects and virtualization of subjects. In this regard, in modern legal science there is an ongoing scientific debate on the definition of the legal nature of artificial intelligence, bots, criteria for their identification. Recognition of artificial intelligence and work as an object or subject of civil rights (legal relations) requires further comprehensive research. Based on the analysis of the current legislation in the area under study, conclusions were formulated regarding the subjects and objects of civil relations arising from digitalization. Exploring the content of civil legal relations, it is noted that the lack of sufficient competence of citizens to work with data (digital skills), appropriate education, professions is a common phenomenon. It is noted that the crisis caused by the COVID-19 pandemic has intensified the digitalization of the public and private spheres of public life.

It is stated that the traditional personal nonproperty and property rights of participants in civil relations are transformed, acquiring a new meaning. The conclusions emphasize the debatability of the impact of digital technologies on civil relations and the need to modernize the civil law regulation of relations using digital objects, digital platforms, digital services, but also doctrinal adjustment of the concept of civil relations regulation in conditions of digitalization, taking into account the experience of $\mathrm{EU}$ countries.

Key words: digitalization, digital technology, civil legal relations, the subject of civil legal relations, the object of civil legal relations, the content of civil legal relation, digital rights, artificial intelligence, virtual enterprise. 